\title{
Nocardioides dubius sp. nov., isolated from an alkaline soil
}

Correspondence

Jung-Hoon Yoon

jhyoon@kribb.re.kr

\author{
Jung-Hoon Yoon, Choong-Hwan Lee and Tae-Kwang Oh \\ Korea Research Institute of Bioscience and Biotechnology (KRIBB), PO Box 115, Yusong, \\ Taejon, Korea
}

\begin{abstract}
A Gram-positive, rod- or coccus-shaped bacterial strain, $\mathrm{KSL}-104^{\top}$, was isolated from an alkaline soil from Korea and its taxonomic position was investigated by a polyphasic approach. Strain $\mathrm{KSL}-104^{\top}$ grew optimally at $\mathrm{pH} 7 \cdot 0-8 \cdot 0$ and $30^{\circ} \mathrm{C}$. It was characterized chemotaxonomically as having a cell-wall peptidoglycan type based on LL-2,6-diaminopimelic acid with MK-8( $\left(\mathrm{H}_{4}\right)$ as the predominant menaquinone. The major fatty acid was iso- $\mathrm{C}_{16: 0}$ and the major polar lipids were diphosphatidylglycerol, phosphatidylglycerol, phosphatidylethanolamine and phosphatidylinositol. The DNA G +C content was 70.6 mol\%. A neighbour-joining phylogenetic tree based on 16S rRNA gene sequences revealed that strain KSL-104 ${ }^{\top}$ joined the cluster comprising Nocardioides jensenii and Marmoricola aurantiacus. The cellular fatty acid profile of strain KSL-104 $4^{\top}$ was different from that of $M$. aurantiacus. Strain KSL-104 ${ }^{\top}$ and the type strain of $N$. jensenii exhibited a $16 \mathrm{~S}$ rRNA gene sequence similarity value of $97 \cdot 1 \%$ and a mean DNA-DNA relatedness value of $13 \%$. Levels of $16 \mathrm{~S} r R N A$ gene sequence similarity between strain KSL- $104^{\top}$ and the type strains of other Nocardioides species were in the range 94.0-96.5\%. On the basis of phenotypic, phylogenetic and genetic data, strain KSL-104 ${ }^{\top}$ (=KCTC $9992^{\top}=\mathrm{JCM} 13008^{\top}$ ) represents a novel species of the genus Nocardioides, for which the name Nocardioides dubius sp. nov. is proposed.
\end{abstract}

The genus Nocardioides was proposed by Prauser (1976) with a single species, Nocardioides albus, and, at the time of writing, the genus comprises 14 species with validly published names (Schippers et al., 2005; Yoon et al., 2005b). Recently, a bacterial strain, KSL-104 $4^{\mathrm{T}}$, containing LL-2,6diaminopimelic acid (DAP) was isolated from an alkaline soil (approximate $\mathrm{pH} 9 \cdot 0-10 \cdot 0$ ) in Korea. 16S rRNA gene sequence analyses indicated that strain KSL- $104^{\mathrm{T}}$ is phylogenetically related to Nocardioides jensenii and Marmoricola aurantiacus. $N$. jensenii was proposed by the reclassification of a species that had been previously assigned to the genus Pimelobacter (Suzuki \& Komagata, 1983; Collins et al., 1989). 16S rRNA gene sequence analyses showed that $N$. jensenii forms an evolutionary lineage at the periphery of the phylogenetic radiation encompassed by the genus Nocardioides and joins the genus Marmoricola with a high bootstrap resampling value (Yoon et al., 1998, 2005a, b; Urzì et al., 2000; Yi \& Chun, 2004a, b). The genus Marmoricola was described by Urzì et al. (2000) with a single species, Marmoricola aurantiacus, which was differentiated from the

Published online ahead of print on 10 June 2005 as DOI 10.1099/ ijs.0.63748-0.

Abbreviation: DAP, 2,6-diaminopimelic acid.

The GenBank/EMBL/DDBJ accession number for the $16 \mathrm{~S}$ rRNA gene sequence of Nocardioides dubius sp. nov. KSL-104 ${ }^{\top}$ is AY928902. genus Nocardioides and from $N$. jensenii by the absence of iso- and anteiso-branched fatty acids, the presence of phosphatidylinositol and the presence of only spherical cells, occurring singly, in pairs, tetrads and small clusters (Urzì et al., 2000). Accordingly, the aim of the present study was to establish the exact taxonomic position of strain KSL- $104^{\mathrm{T}}$ by a polyphasic taxonomic approach.

An alkaline soil collected from Kwangchun, Korea, was used as the source for the isolation of bacterial strains. Strain KSL- $104^{\mathrm{T}}$ was isolated by the standard dilution plating technique at $30^{\circ} \mathrm{C}$ on $10 \times$ diluted nutrient agar (NA; Difco) with the $\mathrm{pH}$ adjusted to $10 \cdot 0$ using $\mathrm{Na}_{2} \mathrm{CO}_{3}$. To investigate its morphological, physiological and biochemical characteristics, strain KSL- $104^{\mathrm{T}}$ was routinely cultivated on NA at $30^{\circ} \mathrm{C}$. N. jensenii KCTC $9134^{\mathrm{T}}$, which was used as the reference strain for DNA-DNA hybridization, was obtained from the Korean Collection for Type Cultures, Taejon, Korea. Morphological, physiological and biochemical properties were examined as described by Yoon et al. (2005c). Growth at various $\mathrm{NaCl}$ concentrations [0-8\% $(\mathrm{w} / \mathrm{v})$ at intervals of $1.0 \%$ ] was investigated in trypticase soy broth (TSB; Difco) lacking $\mathrm{NaCl}$ and TSB supplemented with $\mathrm{NaCl}$. The $\mathrm{pH}$ range for growth was determined in nutrient broth (NB; Difco) that was adjusted to various $\mathrm{pH}$ values (initial $\mathrm{pH} 4 \cdot 0-10 \cdot 5$ at intervals of $0 \cdot 5 \mathrm{pH}$ units). The $\mathrm{pH}$ of the NB was adjusted prior to sterilization by the 
addition of $\mathrm{HCl}$ or $\mathrm{Na}_{2} \mathrm{CO}_{3}$. Other physiological and biochemical tests were performed with the API 20E system (bioMérieux). Cell biomass for the analyses of cell-wall components, isoprenoid quinones, polar lipids and for DNA extraction was obtained by cultivation in $\mathrm{NB}$ at $30^{\circ} \mathrm{C}$. For fatty acid methyl ester analysis, cell mass of strain KSL$104^{\mathrm{T}}$ was harvested from agar plates after incubation for 6 days on NA at $30^{\circ} \mathrm{C}$. Chemotaxonomic and molecular systematic studies were performed as described by Yoon et al. (2005c). Polar lipids were extracted according to Minnikin et al. (1984) and were identified using twodimensional TLC followed by spraying with appropriate detection reagents (Minnikin et al., 1984; Komagata \& Suzuki, 1987).

The morphological, cultural, physiological and biochemical characteristics of strain KSL- $104^{\mathrm{T}}$ are given in the species description (see later) or are shown in Table 1. The $16 \mathrm{~S}$ rRNA gene sequence of strain KSL-104 ${ }^{\mathrm{T}}$ determined in this study comprised $1473 \mathrm{nt}$, representing approximately $96 \%$ of the Escherichia coli 16S rRNA gene sequence. Comparative 16S rRNA gene sequence analyses showed that strain KSL- $104^{\mathrm{T}}$ was phylogenetically affiliated to the genera Nocardioides and Marmoricola (Fig. 1). In the neighbour-joining phylogenetic tree based on 16S rRNA gene sequences, strain KSL- $104^{\mathrm{T}}$ joined the cluster comprising $N$. jensenii and M. aurantiacus with a bootstrap resampling value of $69 \cdot 4 \%$ (Fig. 1). In trees generated with the maximum-likelihood and the maximum-parsimony algorithms, strain KSL- $104^{\mathrm{T}}$ joined the cluster comprising Nocardioides species but excluding $N$. jensenii (data not shown). Strain KSL-104 ${ }^{\mathrm{T}}$ exhibited $16 \mathrm{~S}$ rRNA gene sequence similarity levels of $97 \cdot 1 \%$ compared with the type strain of $N$. jensenii and $94 \cdot 0-96 \cdot 5 \%$ with the type strains of the other Nocardioides species. The similarity value between the $16 \mathrm{~S}$ rRNA gene sequence of strain KSL- $104^{\mathrm{T}}$ and that of M. aurantiacus DSM $12652^{\mathrm{T}}$ was $95 \cdot 4 \%$.

Strain KSL-104 ${ }^{\mathrm{T}}$ contained LL-DAP as the diagnostic diamino acid in the cell-wall peptidoglycan and the predominant menaquinone was MK- $8\left(\mathrm{H}_{4}\right)$, which was the same as that found for Nocardioides species and M. aurantiacus (Yoon et al., 1997, 2004, 2005a, b; Lawson et al., 2000; Urzì et al., 2000; Yi \& Chun, 2004a, b). Strain KSL-104 ${ }^{\mathrm{T}}$ had a cellular fatty acid profile that contained large amounts of branched, unsaturated, straight-chain and 10-methyl fatty acids. Major components ( $>1 \%$ ) were branched fatty acids iso- $\mathrm{C}_{16: 0}(58 \cdot 5 \%)$, iso- $\mathrm{C}_{18: 0}(4 \cdot 3 \%)$, iso- $\mathrm{C}_{16: 1}(3 \cdot 7 \%)$, iso- $\mathrm{C}_{17: 0}(3 \cdot 2 \%)$, iso- $\mathrm{C}_{14: 0}(2 \cdot 5 \%)$, anteiso- $\mathrm{C}_{17: 0}(2 \cdot 0 \%)$ and iso- $\mathrm{C}_{15: 0}(1.9 \%)$, straight-chain fatty acids $\mathrm{C}_{18: 0}$ $(2 \cdot 1 \%)$ and $\mathrm{C}_{16: 0}(1 \cdot 2 \%)$, unsaturated fatty acids $\mathrm{C}_{18: 1} \omega 9 c(1 \cdot 7 \%), \mathrm{C}_{17: 1} \omega 8 c(1 \cdot 3 \%)$ and $\mathrm{C}_{18: 1} \omega 7 c(1 \cdot 1 \%)$ and 10-methyl fatty acids $\mathrm{C}_{17: 0}(7 \cdot 0 \%), \mathrm{C}_{16: 0}(4 \cdot 2 \%)$ and $\mathrm{C}_{18: 0}(2 \cdot 7 \%)$. This fatty acid profile was similar to those of Nocardioides species (Yoon et al., 1997, 2004, 2005a, b; Lawson et al., 2000; Urzì et al., 2000; Yi \& Chun, 2004a). The major polar lipids detected in strain KSL$104^{\mathrm{T}}$ were diphosphatidylglycerol, phosphatidylglycerol,
Table 1. Differential phenotypic characteristics of $N$. dubius sp. nov. and N. jensenii

Data for N. jensenii were taken from Collins et al. (1989), Suzuki \& Komagata (1983) and Yi \& Chun (2004a). The two species are yellowish-white, rods/cocci, are positive or weakly positive for Gram-stain, catalase, alkaline phosphatase, esterase (C4), esterase lipase (C8), leucine arylamidase, hydrolysis of casein and gelatin and for utilization of D-glucose and sucrose. The two species are negative for acid-fastness, lipase (C14), cystine arylamidase, $\alpha$-chymotrypsin, $\alpha$-galactosidase, $\beta$-galactosidase, $\beta$-glucuronidase, $N$-acetyl- $\beta$-glucosaminidase, $\alpha$-fucosidase, $\alpha$-mannosidase, starch hydrolysis and utilization of L-arabinose, D-cellobiose, D-fructose, D-galactose, D-mannose, D-ribose or D-xylose. +, Positive; -, negative; $\mathrm{W}$, weakly positive; $\mathrm{V}$, variable reaction.

\begin{tabular}{|c|c|c|}
\hline Characteristic & N. dubius sp. nov. & N. jensenii \\
\hline Cell size $(\mu \mathrm{m})$ & $0 \cdot 8-1 \cdot 0 \times 1 \cdot 5-2 \cdot 5$ & $0 \cdot 6-0 \cdot 8 \times 3 \cdot 0-7 \cdot 0$ \\
\hline Motility & + & - \\
\hline Oxidase & + & - \\
\hline Nitrate reduction & - & + \\
\hline \multicolumn{3}{|l|}{ Hydrolysis of: } \\
\hline Aesculin & + & - \\
\hline Hypoxanthine & - & + \\
\hline Tween 80 & - & + \\
\hline Tyrosine & - & + \\
\hline Urea & - & + \\
\hline Xanthine & - & + \\
\hline \multicolumn{3}{|l|}{ Utilization of: } \\
\hline Acetate & - & + \\
\hline Benzoate & - & + \\
\hline Citrate & - & $+^{*}$ \\
\hline Salicin & + & - \\
\hline Succinate & + & - \\
\hline \multicolumn{3}{|l|}{ API ZYM: } \\
\hline$\alpha$-Glucosidase & + & $\mathrm{V}$ \\
\hline$\beta$-Glucosidase & + & - \\
\hline Acid phosphatase & + & $\mathrm{V}$ \\
\hline $\begin{array}{l}\text { Naphthol-AS-BI- } \\
\text { phosphohydrolase }\end{array}$ & + & $\mathrm{v}$ \\
\hline Trypsin & - & $\mathrm{W}$ \\
\hline Valine arylamidase & - & $\mathrm{V}$ \\
\hline DNA G +C (mol\%) & $70 \cdot 6$ & $68 \cdot 8$ \\
\hline
\end{tabular}

${ }^{\star}$ Data taken from Yi \& Chun (2004a); a different result was obtained by Suzuki \& Komagata (1983).

phosphatidylethanolamine and phosphatidylinositol. The DNA G + C content of strain KSL- $104^{\mathrm{T}}$ was $70 \cdot 6 \mathrm{~mol} \%$.

Strain KSL- $104^{\mathrm{T}}$ was differentiated from M. aurantiacus by having a rod/coccus life cycle and by exhibiting a different fatty acid profile (Urzì et al., 2000). Phosphatidylinositol was described as being a marker to differentiate the genera Nocardioides and Marmoricola by Urzì et al. (2000), but this polar lipid was also reported to be present in $N$. jensenii and Nocardioides aquaticus (Collins et al., 1989; Lawson 


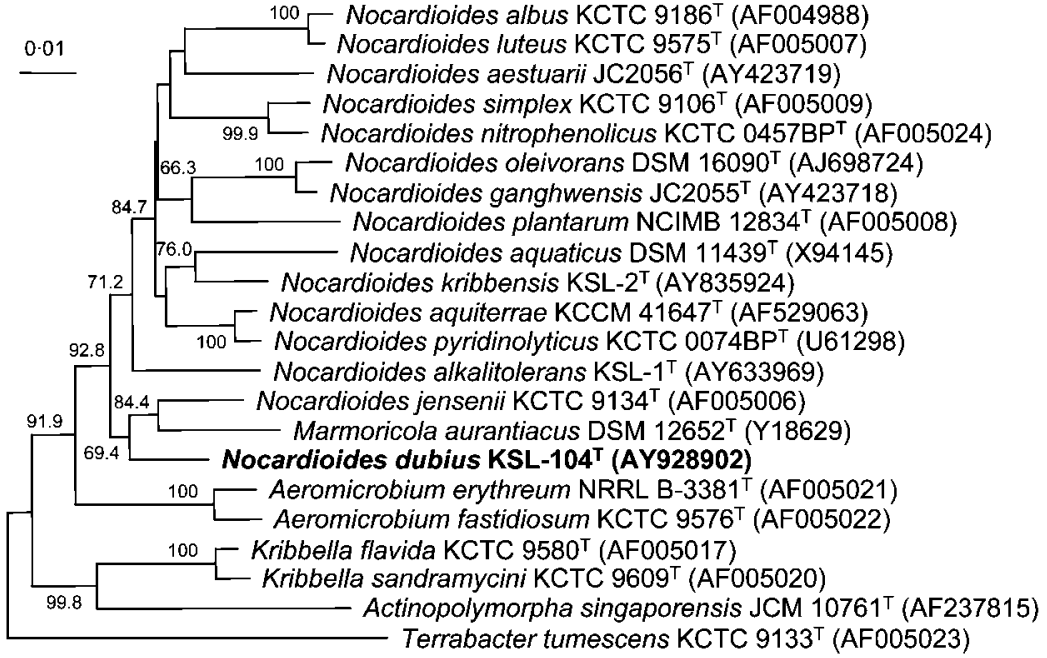

Fig. 1. Neighbour-joining phylogenetic tree based on 16S rRNA gene sequences showing the positions of strain $\mathrm{KSL}-104^{\top}$ and some other related taxa. Bootstrap values (expressed as percentages of 1000 replications) of $>50 \%$ are shown at branch points. Bar, 0.01 substitutions per nucleotide position. et al., 2000). There were not sufficient phenotypic, and particularly chemotaxonomic, properties to distinguish strain KSL-104 ${ }^{\mathrm{T}}$ from the genus Nocardioides (Yoon et al., 1997, 2004, 2005a, b; Lawson et al., 2000; Yi \& Chun, 2004a, b). Although phosphatidylethanolamine was not found in Nocardioides species, inter-specific differences in polar lipid profiles have been found in many other genera as well as in the genus Nocardioides (Collins et al., 1989; Park et al., 1999; Lawson et al., 2000). The chemotaxonomic properties of strain KSL-104 ${ }^{\mathrm{T}}$ were distinguishable from those of the other genera that belong to the family Nocardioidaceae (Miller et al., 1991; Tamura \& Yokota, 1994; Park et al., 1999; Wang et al., 2001). Accordingly, in view of the combined phenotypic and phylogenetic data, it appears to be appropriate for strain KSL- $104^{\mathrm{T}}$ to be placed in the genus Nocardioides. Strain KSL-104 ${ }^{\mathrm{T}}$ was distinguishable from $N$. jensenii by some phenotypic characteristics, in particular, the presence of phosphatidylethanolamine, as listed in Table 1, and the mean DNA-DNA relatedness value with $N$. jensenii KCTC $9134^{\mathrm{T}}$ was $13 \%$. Therefore, on the basis of the data presented, strain KSL-104 ${ }^{\mathrm{T}}$ should be classified in the genus Nocardioides as a representative of a novel species, for which the name Nocardioides dubius sp. nov. is proposed.

\section{Description of Nocardioides dubius sp. nov.}

Nocardioides dubius (du'bi.us. L. masc. adj. dubius doubtful of the taxonomic position).

Cells are aerobic, non-endospore-forming rods $(0 \cdot 8-$ $1 \cdot 0 \times 1 \cdot 5-2 \cdot 5 \mu \mathrm{m})$ in the exponential phase of growth. Cells show rod-to-coccus morphogenesis from the early exponential phase to the stationary phase. Gram-positive. Motile by means of a single polar flagellum. Colonies are irregular, smooth, raised with erose margins, yellowishwhite in colour and $2 \cdot 0-3 \cdot 0 \mathrm{~mm}$ in diameter after 3 days incubation on NA at $30^{\circ} \mathrm{C}$. Neither substrate nor aerial mycelia are formed. Growth occurs at 10 and $37^{\circ} \mathrm{C}$, but not at 4 or $38{ }^{\circ} \mathrm{C}$. Optimal pH for growth is $7 \cdot 0-8 \cdot 0$; growth occurs at $\mathrm{pH} 6 \cdot 0$ and $10 \cdot 5$, but not at $\mathrm{pH} 5 \cdot 5$. Growth occurs in the presence of $0-5 \%(\mathrm{w} / \mathrm{v}) \mathrm{NaCl}$, with an optimum at $0 \%(\mathrm{w} / \mathrm{v}) \mathrm{NaCl}$. Arginine dihydrolase, lysine decarboxylase, ornithine decarboxylase and tryptophan deaminase are absent. $\mathrm{H}_{2} \mathrm{~S}$ and indole are not produced. Tweens 20, 40 and 60 are not hydrolysed. Pyruvate is utilized, but maltose, D-trehalose, formate and L-malate are not. The cell-wall peptidoglycan contains LL-DAP as the diagnostic diamino acid. The predominant menaquinone is MK-8 $\left(\mathrm{H}_{4}\right)$. The major fatty acid is iso- $\mathrm{C}_{16: 0}$. Major polar lipids are diphosphatidylglycerol, phosphatidylglycerol, phosphatidylethanolamine and phosphatidylinositol. The DNA G $+\mathrm{C}$ content is $70 \cdot 6 \mathrm{~mol} \%$ (determined by HPLC). Other phenotypic characteristics are given in Table 1.

The type strain, KSL-104 ${ }^{\mathrm{T}}\left(=\mathrm{KCTC} 9992^{\mathrm{T}}=\mathrm{JCM} 13008^{\mathrm{T}}\right)$, was isolated from an alkaline soil in Kwangchun, Korea.

\section{Acknowledgements}

This work was supported by the 21C Frontier Program of Microbial Genomics and Applications (grant MG02-0401-001-1-0-0) from the Ministry of Science and Technology (MOST) of the Republic of Korea.

\section{References}

Collins, M. D., Dorsch, M. \& Stackebrandt, E. (1989). Transfer of Pimelobacter tumescens to Terrabacter gen. nov. as Terrabacter tumescens comb. nov. and of Pimelobacter jensenii to Nocardioides as Nocardioides jensenii comb. nov. Int J Syst Bacteriol 39, 1-6.

Komagata, K. \& Suzuki, K. (1987). Lipids and cell-wall analysis in bacterial systematics. Methods Microbiol 19, 161-203.

Lawson, P. A., Collins, M. D., Schumann, P., Tindall, B. J., Hirsch, P. \& Labrenz, M. (2000). New LL-diaminopimelic acid-containing actinomycetes from hypersaline, heliothermal and meromictic Antarctic Ekho Lake: Nocardioides aquaticus sp. nov. and Friedmanniella lacustris sp. nov. Syst Appl Microbiol 23, 219-229.

Miller, E. S., Woese, C. R. \& Brenner, S. (1991). Description of the erythromycin-producing bacterium Arthrobacter sp. strain NRRL B3381 as Aeromicrobium erythreum gen. nov., sp. nov. Int J Syst Bacteriol 41, 363-368. 
Minnikin, D. E., O'Donnell, A. G., Goodfellow, M., Alderson, G., Athalye, M., Schaal, A. \& Parlett, J. H. (1984). An integrated procedure for the extraction of bacterial isoprenoid quinones and polar lipids. J Microbiol Methods 2, 233-241.

Park, Y.-H., Yoon, J.-H., Shin, Y. K., Suzuki, K., Kudo, T., Seino, A., Kim, H.-J., Lee, J.-S. \& Lee, S. T. (1999). Classification of 'Nocardioides fulvus' IFO 14399 and Nocardioides sp. ATCC 39419 in Kribbella gen. nov., as Kribbella flavida sp. nov. and Kribbella sandramycini sp. nov. Int J Syst Bacteriol 49, 743-752.

Prauser, H. (1976). Nocardioides, a new genus of the order Actinomycetales. Int J Syst Bacteriol 26, 58-65.

Schippers, A., Schumann, P. \& Spröer, C. (2005). Nocardioides oleivorans sp. nov., a novel crude-oil-degrading bacterium. Int J Syst Evol Microbiol 55, 1501-1504.

Suzuki, K. \& Komagata, K. (1983). Pimelobacter gen. nov., a new genus of coryneform bacteria with LL-diaminopimelic acid in the cell wall. J Gen Appl Microbiol 29, 59-71.

Tamura, T. \& Yokota, A. (1994). Transfer of Nocardioides fastidiosa Collins and Stackebrandt 1989 to the genus Aeromicrobium as Aeromicrobium fastidiosum comb. nov. Int J Syst Bacteriol 44, 608-611.

Urzi, C., Salamone, P., Schumann, P. \& Stackebrandt, E. (2000). Marmoricola aurantiacus gen. nov., sp. nov., a coccoid member of the family Nocardioidaceae isolated from a marble statue. Int J Syst Evol Microbiol 50, 529-536.

Wang, Y. M., Zhang, Z. S., Xu, X. L., Ruan, J. S. \& Wang, Y. (2001). Actinopolymorpha singaporensis gen. nov., sp. nov., a novel actinomycete from the tropical rainforest of Singapore. Int J Syst Evol Microbiol 51, 467-473.

Yi, H. \& Chun, J. (2004a). Nocardioides ganghwensis sp. nov., isolated from tidal flat sediment. Int J Syst Evol Microbiol 54, 1295-1299.

Yi, H. \& Chun, J. (2004b). Nocardioides aestuarii sp. nov., isolated from tidal flat sediment. Int J Syst Evol Microbiol 54, 2151-2154.

Yoon, J.-H., Rhee, S.-K., Lee, J.-S., Park, Y.-H. \& Lee, S. T. (1997). Nocardioides pyridinolyticus sp. nov., a pyridine-degrading bacterium isolated from the oxic zone of an oil shale column. Int J Syst Bacteriol 47, 933-938.

Yoon, J.-H., Lee, S. T. \& Park, Y.-H. (1998). Inter- and intraspecific phylogenetic analysis of the genus Nocardioides and related taxa based on 16S rDNA gene sequences. Int J Syst Bacteriol 48, 187-194.

Yoon, J.-H., Kim, I.-G., Kang, K. H., Oh, T.-K. \& Park, Y.-H. (2004). Nocardioides aquiterrae sp. nov., isolated from groundwater in Korea. Int J Syst Evol Microbiol 54, 71-75.

Yoon, J.-H., Kim, I.-G., Lee, M.-H., Lee, C.-H. \& Oh, T.-K. (2005a). Nocardioides alkalitolerans sp. nov., isolated from an alkaline serpentinite soil in Korea. Int J Syst Evol Microbiol 55, 809-814.

Yoon, J.-H., Kim, I.-G., Lee, M.-H. \& Oh, T.-K. (2005b). Nocardioides kribbensis sp. nov., isolated from an alkaline soil. Int J Syst Evol Microbiol 55, 1611-1614.

Yoon, J.-H., Lee, C.-H. \& Oh, T.-K. (2005c). Aeromicrobium alkaliterrae sp. nov., isolated from an alkaline soil and emended description of the genus Aeromicrobium. Int J Syst Evol Microbiol 55, 2171-2175. 